\title{
Implementasi Model Pembelajaran Kooperatif Tipe CIRC dalam Meningkatkan Kemampuan Menulis Paragraf Deskriptif
}

\author{
M. Zulham \\ Program Studi Pendidikan Guru Sekolah Dasar \\ Fakultas Keguruan dan Ilmu Pendidikan \\ Universitas Cokroaminoto Palopo \\ m.zulham92@yahoo.co.id
}

\begin{abstract}
Abstrak
Penelitian ini bertujuan mengetahui: (1) Kemampuan menulis paragraf deskriptif siswa kelas X SMA Negeri 1 Palopo sebelum dan setelah diterapkan model pembelajaran kooperatif tipe CIRC, (2) peningkatan kemampuan menulis paragraf deskriptif siswa kelas X SMA Negeri 1 Palopo setelah diterapkan model pembelajaran kooperatif tipe CIRC. Satuan eksperimen adalah siswa kelas X SMA Negeri 1 Palopo tahun pelajaran 2019/2020 dengan jumlah siswa 26 orang yang dipilih dengan menggunakan teknik Purposive sampling. Instrumen penelitian yang digunakan adalah tes kemampuan menulis paragraf deskriptif siswa. Pengumpulan data dilakukan dengan pemberian tes awal (pretest) dan tes akhir (posttest). Hasil penelitian menunjukkan bahwa (1) Kemampuan menulis paragraf deskriptif siswa kelas X SMA Negeri 1 Palopo sebelum diterapkan model pembelajaran kooperatif tipe CIRC berada pada kategori sangat rendah, (2) Kemampuan menulis paragraf deskriptif siswa kelas X SMA Negeri 1 Palopo setelah diterapkan model pembelajaran kooperatif tipe CIRC berada pada kategori sedang, (3) Terjadi peningkatan kemampuan menulis paragraf deskriptif siswa kelas X SMA Negeri 1 Palopo setelah diterapkan model pembelajaran kooperatif tipe CIRC. Sehingga dapat disimpulkan bahwa model pembelajaran kooperatif tipe CIRC dapat meningkatkan kemampuan menulis paragraf deskriptif siswa kelas X SMA Negeri 1 Palopo.
\end{abstract}

Kata kunci: Model Pembelajaran Kooperatif Tipe CIRC, Kemampuan Menulis, Paragraf Deskriptif.

\section{Pendahuluan}

Keterampilan menulis sebagai salah satu dari empat keterampilan berbahasa mempunyai peranan penting di dalam kehidupan manusia. Dengan menulis, seseorang dapat mengungkapkan pikiran dan gagasan untuk mencapai maksud dan tujuannya. Seperti yang dinyatakan oleh Tarigan (2008: 22), bahwa menulis ialah menurunkan atau melukiskan lambing grafik yang menggambarkan suatu bahasa yang dipahami oleh seseorang, sehingga orang lain dapat membaca lambang-lambang grafik tersebut apabila mereka memahami bahasa dan gambar grafik itu.

Aktivitas menulis merupakan salah satu manisfestasi kemampuan (dan keterampilan) berbahasa paling akhir yang dikuasai pembelajar bahasa setelah mendengarkan, membaca, dan berbicara, Nurgiyantoro (dalam Siti, 2009: 2). Dalam buku yang sama juga dijelaskan apabila dibandingkan dengan keterampilan berbahasa yang lain, kemampuan menulis lebih sulit dikuasai oleh pembelajar bahasa karena kemampuan menulis menghendaki penguasaan berbagai aspek lain diluar bahasa, untuk menghasilkan paragraf atau wacana yang runtut dan padu. Nurgiyantoro (dalam Siti, 2009: 2) mengungkapkan bahwa 
Volume 6 Nomor 1

menulis adalah aktivitas mengungkapkan gagasan melalui media bahasa. Batasan yang dibuat Nurgiantoro sangat sederhana, menurutnya menulis hanya sekedar mengungkapkan ide, gagasan, atau pendapat dalam bahasa tulis, lepas dari mudah tidaknya tulisan tersebut dipahami oleh pembaca. Kegiatan menulis, khususnya menulis deskripsi dalam dunia persekolahan termasuk dalam aktivitas pembelajaran yang memprihatinkan. Pada jenjang SMA/MA kelas X kegiatan tersebut diwujudkan dengan standar kompetensi yang berbunyi: Menuangkan informasi dalam berbagai bentuk paragraf (narasi, deskripsi, eksposisi). Adapun kompetensi dasar berbunyi: Menulis hasil observasi dalam bentuk paragraph deskripsi.

Selama ini pembelajaran menulis deskripsi dilakukan secara konvensional. Dalam arti siswa diberi sebuah teori menulis deskripsi kemudian siswa melihat contoh dan akhirnya siswa ditugasi untuk membuat paragraf atau wacana deskripsi baik secara langsung atau dengan jalan melanjutkan tulisan yang ada. Kesimpulan tersebut diperkuat dengan adanya fakta bahwa media atau sumber belajar yang variatif tidak dimunculkan oleh guru. Sumber belajar diluar guru yang dapat dimanfaatkan oleh siswa yaitu buku teks dan LKS bahasa Indonesia. Oleh karena itu, suasana belajar mengajar tentang keterampilan menulis menjadi membosankan dan siswa merasa jenuh mengikuti proses pembelajaran tersebut. Selain itu siswa belum mampu mengidentifikasikan sebuah peristiwa atau pungambara nyan gada dalam pikiran masing-masing untuk dirangkai ke dalam bentuk tulisan atau dalam kata lain siswa kurang dapat menggali ide dan gagasan. Padahal guru sudah menentukan tema tulisan secara jelas.

Penelitian tentang peningkatan keterampilan menulis dengan menggunakan metode pembelajaran kooperatif dilakukan karena melihat kondisi siswa dalam menerima materi menulis belum sesuai dengan harapan. Selain itu, peneliti beranggapan metode pengajaran dan pembelajaran yang digunakan oleh guru dengan metode ceramah dan media contoh-contoh belum mengalami perubahan terhadap hasil pekerjaan siswa dalam menulis. Masalah lain yang muncul siswa akan berpersepsi negatif terhadap materi menulis, karena metode dan media yang digunakan terkesan membosankan dan membingungkan.

Mengatasi kondisi seperti itu, peneliti menawarkan satu solusi untuk meningkatkan kemampuan siswa dalam menulis paragraf deskriptif. Adapun solusi yang ditawarkan peneliti adalah penggunaan metode pembelajaran kooperatif. Salah satu aspek penting dalam pembelajaran kooperatif adalah pembelajaran kooperatif dapat membantu mengembangkan tingkah laku kooperatif siswa, secara bersamaan membantu siswa dalam pembelajaran akademis mereka.

Pembelajaran kooperatif yangdigunakan peneliti dalam penelitian ini adalah pembelajaran kooperatif terpadu membaca dan menulis (CIRC: Cooperative Integrated Reading and Composition). Slavin mengemukakan bahwa pembelajaran dilaksanakan secara terpadu sehingga keterampilan membaca dan menulis dapat berkembang secara seimbang. Dengan demikian keterampilan menulis juga akan 
Volume 6 Nomor 1

mengalami perkembangan seiring dengan intensitas kegiatan membaca yang dilaksanakan. Metode pembelajaran CIRC sebagai salah satu cara untuk membelajarkan menulis paragraph deskriptif kepada siswa akan dapat menolong siswa mengembangkan kualitas menulis paragraf deskriptif.

Menulis merupakan salah satu dari empat keterampilan berbahasa. Menulis bukanlah hal yang sulit namun tidak juga dikatakan mudah. Menulis dikatakan bukan hal yang sulit bila menulis hanya diartikan sebagai aktivitas mengungkapkan gagasan melalui lambang-lambang grafis tanpa memperhatikan unsure penulisan dan unsur diluar penulisan seperti pembaca. Sementara itu, sebagian besar orang berpendapat bahwa menulis bukan hal yang mudah sebab diperlukan banyak bekal bagi seseorang untuk keterampilan menulis.

Para pakar banyak memberikan pendapat tentang kemampuan menulis. Donnn Byrne (dalam Semi, 1998: 8), mengemukakan, menulis bukan sesuatu yang diperoleh secara spontan, tetapi memerlukan usaha sadar "menuliskan" kalimat dan mempertimbangkan cara mengkomunikasikan dan mengatur.

Menulis arti pertamanya semula membuat huruf, angka, nama, dan sesuatu tanda kebahasaan apapun dengan sesuatu alat tulis pada suatu halaman tertentu, kini dalam pengertian yang luas menulis merupakan kata sepadan yang mempunyai arti sama dengan mengarang. Jadi "mengarang" adalah rangkaian kegiatan seseorang mengungkapkan gagasan dan menyampaikan melalui bahasa tulis kepada masyarakat pembaca untuk dipahami, (dalam Gie, 2002: 3).

Menurut Tarigan (1995: 117) menulis berarti mengekspresikan secara tertulis gagasan, ide, pendapat, atau pikiran dan perasaan. Sarana mewujudkan hal itu adalah bahasa. Isi ekspresi melalui bahasa itu akan dimengerti orang lain atau pembaca bila dituangkan dalam bahasa yang teratur, sistematis, sederhana, dan mudah dimengerti.

Sejalan dengan itu, menurut Lado (dalam Semi, 1998: 14) menulis adalah meletakkan symbol grafis yang mewakili bahasa yang dimengerti orang lain. Jadi, orang lain dapat membaca symbol grafis itu, jika mengetahui bahwa itu menjadi bagian dari ekspresi bahasa. Semi (1998: 8) juga mengatakan bahwa menulis pada hakikatnya merupakan pemindahan pikiran atau perasaan ke dalam bentuk lambing bahasa. Menurut Gere (dalam Haduyanto, 2001: 4), menulis dalam arti komunikasi ialah menyampaikan pengetahuan atau informasi tentang subjek. Menulis berarti mendukung ide. Byrne (dalam Kusumah, 2003: 2), mengatakan bahwa menulis tidak hanya membuat satu kalimat atau hanya beberapa hal yang tidak berhubungan, tetapi menghasilkan serangkaian hal yang teratur, yang berhubungan satu dengan yang lain, dan dalam gaya tertentu. Rangkaian kalimat itu bias pendek, mungkin hanya dua atau tiga kalimat, tetapi kalimat itu diletakkan satu dengan yang lain, dan berbentuk kesatuan yang masuk akal. Crimmon (dalam Gie, 2002: 91), berpendapat bahwa menulis adalah kerja keras, tetapi juga merupakan kesempatan untuk menyampaikan sesuatu tentang diri sendiri mengkomunikasikan gagasan kepada orang lain, bahkan dapat mempelajari sesuatu yang belum diketahui. 
Volume 6 Nomor 1

Lebih lanjut Rusyana (dalam Akhadiat, 1996: 191), memberikan batasan bahwa kemampuan menulis atau mengarang adalah kemampuan menggunakan pola- pola bah asa dalam tampilan tertulis untuk mengungkapkan gagasan atau pesan. Kemampuan menulis mencakup berbagai kemampuan, seperti kemampuan menguasai gagasan yang dikemukakan, kemampuan menggunakan unsur-unsur bahasa, kemampuan menggunakan gaya, dan kemampuan menggunakan ejaan serta tanda baca.

Berdasarkan konsep diatas, dapat dikatakan bahwa menulis merupakan komunikasi tidak langsung yang berupa pemindahan pikiran atau perasaan dengan memanfaatkan grafologi, struktur bahasa, dan kosakata dengan menggunakan simbol-simbol sehingga dapat dibaca seperti apa yang diwakili oleh simbol tersebut.

Menurut Semi (dalam Siti, 2009: 14) terdapat empat bentuk pengembangan tulisan yaitu narasi, deskripsi, eksposisi, dan argumentasi. Sementara itu, Keraf (1981: 6-7) membagi karangan atau wacana menjadi lima jenis berdasarkan tujuan umum yang tersirat dibalik wacana tersebut, yaitu eksposisi, argumentasi, persuasi, deskripsi, dan narasi.

Menurut Tarigan (2008: 23) setiap jenis tulisan mengandung beberapa tujuan, tetapi karena tujuan itu sangat beranekaragam, maka bagi penulis yang belum berpengalaman ada baiknya memperhatikan tujuan menulis, yaitu memberitahukan (informative), meyakinkan (persuasive), menghibur (literally), mengekspresikan perasaan dan emosi(ekspresive).

Deskripsi berasal dari kata decription yang berarti uraian atau lukisan. Arti deskripsi menurut Keraf (1994: 15) merupakan sebuah bentuk tulisan yang bertahan dengan usaha para penulis untuk memberikan perincian-perincian dan objek yang sedang dibicarakan. Kata deskripsi berasal dari kata Latin describera yang berarti menulis tentang atau membeberkan sesuatu hal, sebaliknya kata deskripsi dapat diterjemahkan menjadi pemerian yang berasal dari kata perimemerikan yang berarti melukiskan sesuatu hal.

Dari segi istilah, deskripsi adalah suatu bentuk karangan yang melukiskan sesuatu sesuai dengan keadaan sebenarnya, sehingga pembaca dapat mencitrai (melihat, mendengar, mencium, dan merasakan) apa yang dilukiskan itu sesuai dengan citra penulisnya. Karangan jenis ini bermaksud menyampaikan kesankesan tentang sesuatu, dengan sifat dan gerak-geriknya atau sesuatu yang lain kepada pembaca, Yunus (2007: 4.22). Hal yang sama juga diungkapkan oleh Sumarlam (dalam Siti, 2009: 15) wacana deskripsi pada dasarnya berupa rangkaian tuturan yang memaparkan atau melukiskan sesuatu baik berdasarkan pengalaman maupun pengetahuan penuturnya.

Tujuan yang ingin dicapai oleh wacana ini adalah tercapainya pengalaman yang agak jenis ini bermaksud menyampaikan kesan-kesan tentang sesuatu, dengan sifat dan gerak-geriknya atau sesuatu yang lain kepada pembaca, Yunus (2007: 4.22). Hal yang sama juga diungkapkan oleh Sumarlam (dalam Siti, 2009: 15) wacana deskripsi pada dasarnya berupa rangkaian tuturan yang memaparkan 
atau melukiskan sesuatu baik berdasarkan imajinatif terhadap sesuatu, sehingga pembaca atau pendengar merasa seolah-olah mengalami atau mengetahuinya secara langsung. Sedangkan dalam menulis efektif deskripsi adalah tulisan yang tujuannya memberikan perincian atau detail tentang objek sehingga dapat memberi pengaruh pada sensitivitas dan imajinasi pembaca atau pendengar. Bagaimana mereka ikut melihat atau mendengar, merasakan atau mengalami sendiri secara langsung objek tersebut, Semi (dalam Siti, 2009: 16). Interpretasi penulis dalam wacana deskripsi sangat kuat pengaruhnya. Kemunculan wacana deskripsi hamper selalu menjadi bagian dari wacana yang lain. Objek yang dipaparkan dalam wacana deskripsi misalnya tentang sketsa pemandangan, perwatakan, suasana ruang, dan lain-lain. Semi (dalam Siti, 2009: 16) menyatakan beberapa ciri tanda penulisan atau karangan deskripsi yaitu:

a. Deskripsi lebih berupaya memperlihatkan detail atau perincian tentang objek.

b. Deskripsi lebih bersifat memberi pengaruh sensitivitas.

c. Deskripsi disampaikan dengan gaya memikat dan dengan pilihan kata (diksi) yang menggugah.

d. Deskripsi lebih banyak memaparkan tentang sesuatu yang dapat didengar, dilihat, dan dirasakan sehingga objeknya pada umumnya benda, alam, warna, dan manusia.

e. Organisasi penyampaian lebih banyak menggunakan susunan paparan terhadap suatu detail.

Untuk mendapatkan tulisan deskripsi yang baik ada tiga pendekatan yang harus dilakukan oleh penulis, Yunus (2007: 4.8-4. 11) yaitu:

a. Pendekatan ekspositoris

Dalam pendekatan ekspositoris penulis berusaha agar deskripsi yang dibuatnya dapat memberi keterangan sesuai dengan keadaan yang sebenarnya sehingga pembaca dapat seolah-olah ikut melihat atau merasakan objek yang dideskripsikan. Karangan jenis ini berisi daftar detail sesuatu secara lengkap atau agak lengkap sehingga pembaca dengan penalarannya dapat memperoleh kesan keseluruhan tentang sesuatu. Efek pemerolehan kesan tersebut lebih banyak didasarkan atas proses penalaran dari pada emosional.

b. Pendekatan yang impresionistik

Pendekatan yang berusaha menggambarkan sesuatu secara subjektif. Apa yang dimaksud dengan subjektif sama sekali tidak berarti bahwa pengarang itu membuat seenaknya terhadap detail-detail yang dapat dilihatnya. Tujuan deskripsi impresionistik ialah untuk mendapatkan tanggapan emosional pembaca ataupun kesan pembaca. Corak deskripsi ini di antaranya juga ditentukan oleh macam kesan apa yang diinginkan penulisnya.

c. Pendekatan menurut sikap penulis

Pendekatan ini sangat bergantung pada tujuan yang ingin dicapai, sifat objek, serta pembaca deskripsinya. Dalam menguraikan sebuah gagasan, penulis mungkin mengharapkan agar pembaca merasa tidak puas terhadap suatu tindakan atau keadaan, atau penulis menginginkan agar pembaca juga harus merasakan 
Volume 6 Nomor 1

bahwa persoalan yang tengah dihadapi merupakan masalah yang gawat. Penulis juga dapat membayangkan bahwa akan terjadi sesuatu yang tidak diinginkan, sehingga pembaca dari mula sudah disiapkan dengan perasaan yang kurang enak, seram, takut dan sebagainya Pengarang harus menetapkan sikap yang akan diterapkan sebelum mulai menulis. Semua detail harus dipusatkan untuk menunjang efek yang ingin dihasilkan. Perincian yang tidak ada kaitannya dan menimbulkan keragu-raguan pada pembaca, harus disingkirkan. Penulis dapat memilih salah satu sikap seperti masa bodoh, sungguh-sungguh dan cermat, mengambil sikap seenaknya, atau mengambil sikap bertindak ironis.

Menurut Slavin (dalam Solihatin, 2007: 4) “cooperative learning adalah suatu model pembelajaran dimana siswa belajar dan bekerja dalam kelompokkelompok kecil secara kolaboratif yang anggotanya 4-5 orang dengan struktur kelompok heterogen". Isjoni (dalam Solihatin, 2007:4) menyatakan bahwa "cooperative learning dapat diterapkan untuk memotivasi siswa berani mengemukakan pendapatnya, menghargai pendapat teman, dan saling memberikan pendapat (sharing ideas) serta siswa dapat bekerjasama dan saling tolong-menolong mengatasi tugas yang dihadapinya".

Dari berbagai pengertian di atas dapat disimpulkan bahwa pembelajaran kooperatif adalah suatu model pembelajaran dimana siswa dibagi ke dalam kelompok-kelompok kecil untuk saling bekerjasama dan saling tolong-menolong dalam mengatasi tugas yang dihadapinya. Siswa dibagi menjadi kelompokkelompok kecil agar siswa lebih memahami materi pelajaran serta dapat lebih bekerjasama dengan siswa yang lain.

Kooperatif mengandung pengertian bekerjasama dalam mencapai tujuan bersama. Dalam kegiatan kooperatif, siswa secara individual mencari hasil yang menguntungkan bagi seluruh anggota kelompoknya. Jadi belajar kooperatif adalah pemanfaatan kelompok kecil dalam pengajaran yang memungkinkan siswa bekerja sama untuk memaksimalkan belajar mereka dan belajar anggota lainnya dalam kelompok tersebut. Pembelajaran kooperatif lebih dari sekedar belajar kelompok atau kelompok kerja, karena belajar dalam model pembelajaran kooperatif harus ada "struktur dorongan dan tugas yang bersifat kooperatif" sehingga memungkinkan terjadinya interaksi secara terbuka dan hubungan-hubungan yang bersifat interdependensi yang efektif di antara anggota kelompok. Di samping itu, pola hubungan kerja seperti itu memungkinkan timbulnya persepsi yang positif tentang apa yang dapat mereka lakukan untuk berhasil berdasarkan kemampuan dirinya secara individual dan sumbangsih dari anggota lainnya selama mereka belajar secara bersama-sama dalam kelompok. Stahl (dalam Solihatin, 2007: 5) mengatakan bahwa model pembelajaran pembelajaran kooperatif menempatkan siswa sebagai bagian dari suatu sistem kerjasama dalam mencapai suatu hasil yang optimal dalam belajar. Model pembelajaran ini berangkat dari asumsi mendasar dalam kehidupan masyarakat, yaitu "getting better together", atau "raihlah yang lebih baik secara bersama- sama" Slavin (dalam Solihatin, 2007: 5). 
Volume 6 Nomor 1

Aplikasinya di dalam pembelajaran di kelas, model pembelajaran ini mengetengahkan realita kehidupan masyarakat yang dirasakan dan dialamai oleh siswa dalam kesehariannya, dengan bentuk yang disederhanakan dalam kehidupan kelas. Model pembelajaran ini memandang bahwa keberhasilan dalam belajar bukan semata-mata harus diperoleh dari guru, melainkan bisa juga dari pihak lain yang terlibat dalam pembelajaran itu, yaitu teman sebaya. Keberhasilan belajar menurut model belajar ini bukan semata-mata ditentukan oleh kemampuan individu secara utuh, melainkan perolehan belajar itu akan semakin baik apabila dilakukan secara bersama-sama dalam kelompok-kelompok belajar kecil yang terstruktur dengan baik. Melalui belajar dari teman yang sebaya dan dibawah bimbingan guru, maka proses penerimaan dan pemahaman siswa akan semakin mudah dan cepat terhadap materi yang dipelajari.

Pembelajaran kooperatif adalah suatu sistem yang di dalamnya terdapat elemenelemen yang terkait. Adapun berbagai elemen dalam pembelajaran kooperatif adalah adanya: (1) saling ketergantungan positif, (2) interaksi tatap muka, (3) akuntabilitas individual, (4) keterampilan untuk menjalin hubungan antar pribadi dan keterampilan social yang secara sengaja diajarkan, Abdurrahman dan Bintoro (dalam Solihatin, 2007: 5).

Pembelajaran CIRC dikembangkan oleh Stevans, Madden, Slavin, dan Farnish. CIRC merupakan singkatan dari Cooperative Integrated Reading and Composition, termasuk salah satu model pembelajaran cooperative learning yang pada mulanya merupakan pengajaran kooperatif terpadu membaca dan menulis, Slavin (dalam Melki, 2011: 32) yaitu sebuah program komprehensif atau luas dan lengkap untuk pengajaran membaca dan menulis untuk kelas-kelas tinggi. Dalam metode pembelajaran $C I R C$, siswa ditempatkan dalam kelompok-kelompok kecil yang heterogen, yang terdiri dari 4 sampai 5 siswa. Dalam kelompok ini tidak dibedakan atas jenis kelamin, suku/bangsa, atau tingkat kecerdasan siswa. Jadi, dalam kelompok ini sebaiknya ada siswa yang pandai, sedang atau lemah, dan masing-masing siswa merasa cocok satu sama lain. Dengan pembelajaran kooperatif, siswa diharapkan dapat meningkatkan cara berpikir kritis, kreatif dan menumbuhkan rasa sosial yang tinggi.

Pada awalnya model CIRC diterapkan dalam pembelajaran bahasa. Dalam kelompok kecil para siswa diberi suatu teks bacaan (cerita/novel) kemudian siswa latihan membaca atau saling membaca, memahami ide pokok, saling merevisi, dan menulis ikhtisar cerita atau tanggapan terhadap isi cerita atau untuk mempersiapkan tugas tertentu dari guru, Mohammad Nur (dalam Melki, 2011: 32).

Pengembangan CIRC yang secara simultan difokuskan pada kurikulum dan pada metode-metode pengajaran merupakan sebuah upaya untuk menggunakan pembelajaran kooperatif sebagai sarana untuk memperkenalkan teknik terbaru latihan-latihan kurikulum yang berasal terutama dari penelitian dasar mengenai pengajaran praktis pelajaran membaca dan menulis. Metode pembelajaran kooperatif mengikuti penemuan dan penelitian sebelumnya, 
menekankan tujuan kelompok dan tanggung jawab individual. Sebagai tambahan, pengembangan $C I R C$ dihasilkan dari sebuah analisis masalah-masalah tradisional dalam pengajaran pelajaran membaca, menulis dan seni berbahasa. Salah satu fokus utama dari kegiatan- kegiatan CIRC sebagai cerita dasar adalah membuat penggunaan waktu tindak lanjut menjadi lebih efektif. Para siswa yang bekerja di dalam tim-tim kooperatif dari kegiatan-kegiatan ini, yang dikoordinasikan dengan pengajaran kelompok membaca, supaya dapat memenuhi tujuan-tujuan dalam bidang-bidang lain seperti pemahaman membaca, kosakata, pembacaan pesan, dan ejaan. Para siswa termotivasi untuk saling bekerja satu sama lain dalam kegiatan-kegiatan ini atau rekognisi lainnya yang didasarkan pada pembelajaran seluruh anggota tim, Slavin (dalam Melki, 2011: 33).

Tujuan utama dari CIRC adalah menggunakan tim-tim kooperatif untuk membantu para siswa mempelajari kemampuan memahami bacaan yang dapat diaplikasikan secara luas. Beberapa unsur CIRC memang diarahkan untuk tujuan ini. Para siswa dalam $C I R C$ juga membuat penjelasan terhadap prediksi mengenai bagaimana masalah-masalah akan diatasi dan merangkum unsur-unsur utama dari cerita kepada satu sama lain Slavin, (dalam Melki, 2011: 33). Pembelajaran kooperatif terpadu membaca dan menulis (Cooperatif Integrated Readingand Composition: $C I R C$ ) merupakan model pembelajaran yang menggabungkan proses belajar membaca dan menulis. Pembelajaran dilaksanakan secara terpadu sehingga keterampilan membaca dan menulis dapat berkembang secara seimbang.

Cooperatif Integrated Reading and Composition (CIRC) adalah salah satu metode pembelajaran kooperatif yang paling efektif dalam pelajaran membaca, menulis, dan seni berbahasa, Heathman (dalam Melki, 2011: 33). Oleh sebab itu, dalam pembelajaran menulis paragraph deskripsi juga memerlukan metode $C I R C$ tersebut. Metode pembelajaran CIRC sangat berbeda dengan metode pembelajaran lain. Beberapa ahli berpendapat bahwa metode ini unggul dalam membantu siswa memahami konsep-konsep yang sulit. Di samping itu, tujuan penting lain yang terdapat dalam metode pembelajaran CIRC adalah untuk mengajarkan siswa keterampilan kerjasama dan kolaborasi.

Slavin (dalam Melki, 2011: 34) menyebutkan kelebihan metode pembelajaran $C I R C$ sebagai berikut:

a. CIRC amat tepat untuk meningkatkan keterampilan siswa dalam menyelesaikan soal pemecahan masalah.

b. Dominasi guru dalam pembelajaran berkurang.

c. Siswa termotivasi pada hasil secara teliti, karena bekerja dalam kelompok.

d. Para siswa dapat memahami makna soal dan saling mengecek pekerjaannya.

e. Membantu siswa yang lemah.

f. Meningkatkan hasil belajar khususnya dalam menyelesaikan soal yang berbentuk penyelesaian masalah. 
Volume 6 Nomor 1

Steven dan Slavin (dalam Melki, 2011: 34) mengemukakan bahwa metode pembelajaran kooperatif terpadu membaca dan menulis atau cooperative intergrated reading and composition (CIRC) merupakan metode pembelajaran dengan langkah-langkah sebagai berikut (1) membentuk kelompok yang anggotanya 4 orang secara heterogen, (2) guru memberikan bacaan sesuai dengan topik pembelajaran, (3) siswa bekerja sama saling membacakan dan menemukan ide pokok dan memberi tanggapan terhadap wacana atau kliping dan ditulis pada lembar kertas, (4) atau membacakan hasil kelompok, (5) guru membuat kesimpulan bersama, dan (6) penutup.

Menurut Suprijono (dalam Melki, 2011: 34), langkah-langkah yang dilakukan seorang guru dalam melaksanakan kegiatan pembelajaran kooperatif tipe $C I R C$ adalah sebagai berikut:

a. Membentuk kelompok yang anggotanya 4-5 orang secara heterogen.

b. Guru memberikan wacana/ klipping sesuai dengan topik pembelajaran.

c. Siswa bekerjasama saling membacakan dan menemukan ide pokok dan memberi tanggapan terhadap wacana/klipping dan ditulis pada lembar kertas.

d. Siswa membacakan hasil kelompok.

e. Guru membuat kesimpulan.

f. Penutup

\section{Metode Penelitian}

Penelitian ini dilaksanakan di SMA Negeri 1 Kota Palopo. Penelitian ini dilakukan pada semester ganjil tahun pelajaran 2019/2020 yaitu pada bulan September sampai dengan bulan November 2019. Jenis penelitian ini adalah penelitian eksperimen. Desain penelitian yang digunakan adalah One-Group PretestPosttest Design.

Satuan eksperimen dalam penelitian ini adalah siswa kelas X SMA Negeri 1 Palopo tahun pelajaran 2019/2020. Pemilihan kelas eksperimen dalam penelitian ini dilakukan dengan menggunakan Purposive Sampling.

Instrumen penelitian yang digunakan dalam penelitian ini adalah tes kemampuan menulis paragraf deskriptif siswa.

a. Pretest adalah untuk mengukur penguasaan awal siswa terhadap materi pelajaran sebelum pelaksanaan pembelajaran.

b. Posttest adalah untuk mengukur penguasaan bahan ajar siswa setelah pelaksanaan proses pembelajaran dengan menggunakan model pembelajaran kooperatif tipe CIRC.

Dalam penelitian ini, Pengumpulan data untuk hasil menulis paragraf deskriptifsiswa dilakukan dengan dua tahap. Tahap pertama yaitu pemberian tes awal. Tes awal diberikan pada saat pertemuan pertama. Tahap kedua yaitu pemberian tes akhir (posttest). Hasil dari pretest maupun posttest yang sudah diisi oleh siswa diperiksa jawabannya oleh peneliti. Setelah perhitungan selesai, maka hasil dari perhitungan itu adalah nilai yang diperoleh oleh masing-masing siswa. 
Untuk mengukur hasil kemampuan menulis paragraf deskriptif siswa menurut Nurkancana (Nurhida, 2015:49) yaitu skor hasil menulis.

$0 \quad-54 \quad$ : dikategorikan sangat rendah

$55 \quad-64 \quad$ : dikategorikan rendah

65 - $79 \quad$ : dikategorikan sedang

80 - $89 \quad$ : dikategorikan tinggi

$90 \quad-100 \quad$ : dikategorikan sangat tinggi

Adapun kriteria peningkatan kemampuan menulis paragraf deskriptfi siswa dapat dilihat pada tabel berikut.

Tabel 2. Kriteria Skor Peningkatan

\begin{tabular}{cc}
\hline Skor Gain & Interpretasi \\
\hline $\mathrm{g}<0,3$ & Rendah \\
$0,3 \leq \mathrm{g}<0,7$ & Sedang \\
$\mathrm{g} \geq 0,7$ & Tinggi \\
\hline
\end{tabular}

Sumber: Nurhida (2015:49)

Dihitung dengan menggunakan rumus:

Keterangan:

$$
g=\frac{S_{\text {pos }}-S_{\text {pre }}}{S_{\text {mak }}-S_{\text {pre }}}
$$

$$
\begin{aligned}
& \mathrm{g}=\text { gain ternormalisasi } \\
& \mathrm{S}_{\text {pre }}=\text { Skor pretest } \\
& \mathrm{S}_{\text {pos }}=\text { Skor posttest } \\
& \mathrm{S}_{\text {mak }}=\text { Skor maksimum ideal }
\end{aligned}
$$

\section{Hasil Penelitian}

Berikut ini adalah tabel yang berisi tentang gambaran umum skor hasil kemampuan menulis paragraf deskriptif siswa sebelum dan setelah diajar dengan menggunakan model pembelajaran kooperatif tipe CIRC yang diperoleh dari data hasil pretest dan posttest.

Tabel 3. Statistik Deskriptif Hasil Kemampuan Menulis Paragraf Deskriptif Siswa Sebelum dan Setelah Diterapkan Model Pembelajaran Kooperatif Tipe CIRC

\begin{tabular}{lrr}
\hline \multirow{2}{*}{\multicolumn{1}{c}{ Statistik }} & \multicolumn{2}{c}{ Nilai Statistik } \\
\cline { 2 - 3 } & Pretest & Postest \\
\hline Ukuran sampel & 26,00 & 26,00 \\
Nilai maksimum & 65,00 & 57,00 \\
Nilai minimum & 30,00 & 54,00 \\
Nilai rata-rata & 50,07 & 73,03 \\
Deviasi standar & 9,35 & 11,86 \\
Variansi & 87,51 & 140,83 \\
\hline
\end{tabular}


Volume 6 Nomor 1

Berdasarkan tabel 3 data hasil kemampuan menulis paragraf deskriptif siswa pada pretest terlihat bahwa nilai rata-rata 50,07 sedangkan pada posttest terlihat bahwa nilai rata-rata 73,03. Secara deskriptif dapat dikatakan bahwa kemampuan menulis paragraf deskriptif siswa kelas $\mathrm{X}_{1}$ SMA Negeri 1 Palopo menjadi lebih baik dari pada sebelum diberikan pembelajaran dengan menggunakan model pembelajaran kooperatif tipe CIRC

Besarnya peningkatan hasil kemampuan menulis paragraf deskriptifsiswa yang diajar dengan menggunakan model pembelajaran kooperatif tipe CIRC yang dihitung dengan rumus gain ternormalisasi.

$$
\begin{gathered}
\mathrm{g}=\frac{\mathrm{S}_{\text {pos }}-S_{\text {pre }}}{\mathrm{S}_{\mathrm{mak}}-S_{\text {pre }}} \\
\mathrm{g}=\frac{73,03-50,07}{100-50,07} \\
\mathrm{~g}=\frac{22,96}{49,93} \\
\mathrm{~g}=0,46
\end{gathered}
$$

Berdasarkan tabel kriteria peningkatan kemampuan menulis paragraf deskriptifsiswa setelah diterapkannya model pembelajaran kooperatif tipe CIRC berada pada kategori sedang.

1) Hasil Kemampuan Menulis Paragraf Deskriptif Siswa Sebelum Diterapkan Model Pembelajaran Kooperatif Tipe CIRC

Hasil analisis statistik deskriptif berkaitan dengan skor variabel hasil kemampuan menulis paragraf deskriptif siswa sebelum diajar dengan model pembelajaran kooperatif tipe CIRC disajikan dalam tabel 4.

Tabel 4.Statistik Deskriptif Kemampuan Menulis Paragraf Deskriptif Siswa Kelas $\mathrm{X}_{1}$ SMA Negeri 1 Palopo Sebelum Diterapkan Model Pembelajaran Kooperatif Tipe CIRC

\begin{tabular}{lc}
\hline \multicolumn{1}{c}{ Statistik } & Nilai Statistik \\
\hline Banyak Sampel & 26 \\
Nilai Tengah & 51,66 \\
Skor Maksimum & 65,00 \\
Skor Minimum & 30,00 \\
Rentang Skor & 35,00 \\
Rata-rata & 50,07 \\
Standar Deviasi & 9,35 \\
Variansi & 87,51 \\
\hline
\end{tabular}

Sumber: Hasil Analisis Data Primer (2019)

Berdasarkan tabel 4nilai tertinggi yang diperoleh siswa adalah 65, nilai terendah 30, dengan rentang skor 35. Jika skor hasil kemampuan menulis paragraf deskriptif siswa kelas $\mathrm{X}_{1}$ SMA Negeri 1 Palopo sebelum diterapkan model 
Volume 6 Nomor 1

pembelajaran kooperatif tipe CIRC dikelompokkan dalam lima kategori menurut Nurkancana (Nurhida, 2015:49), maka diperoleh tabel distribusi frekuensi dan presentase hasil kemampuan menulis paragraf deskriptif seperti ditunjukkan pada tabel berikut ini.

Tabel 5.Distribusi Frekuensi Hasil Kemampuan Menulis Paragraf Deskriptif Siswa Kelas $\mathrm{X}_{1}$ SMA Negeri 1 Palopo Sebelum Diterapkan Model Pembelajaran Kooperatif Tipe CIRC

\begin{tabular}{cccc}
\hline Skor & Kategori & Frekuensi & $\begin{array}{l}\text { Presentase } \\
\text { (\%) }\end{array}$ \\
\hline $0-54$ & Sangat Rendah & 13 & 50,00 \\
$55-64$ & Rendah & 11 & 42,00 \\
$65-79$ & Sedang & 2 & 8,00 \\
$80-89$ & Tinggi & 0 & 0 \\
$90-100$ & Sangat Tinggi & 0 & 0 \\
\hline & Jumlah & 26 & 100 \\
\hline
\end{tabular}

Sumber: Hasil Analisis Data Primer (2019)

Dari tabel di atas menunjukkan bahwa dari 26 siswa kelas $\mathrm{X}_{1}$ SMA Negeri 1 Palopo yang menjadi sampel pada penelitian (pretest) hasil kemampuan menulis paragraf deskriptif siswa sebelum diterapkan model pembelajaran kooperatif tipe CIRC berada pada kategori sangat rendah.

2) Hasil Kemampuan Menulis Paragraf Deskriptif Siswa Setelah Diterapkan Model Pembelajaran Kooperatif Tipe CIRC

Hasil analisis statistika deskriptif berkaitan dengan skor variabel hasil kemampuan menulis paragraf deskriptif siswa setelah diajar dengan model pembelajaran kooperatif tipe CIRC disajikan dalam tabel 6berikut.

Tabel 6. Statistik Deskriptif Kemampuan Menulis Paragraf Deskriptif Siswa Kelas $\mathrm{X}_{1}$ SMA Negeri 1 Palopo Setelah Diterapkan Model Pembelajaran Kooperatif Tipe CIRC

\begin{tabular}{lc}
\hline \multicolumn{1}{c}{ Statistik } & Nilai Statistik \\
\hline Banyak Sampel & 26 \\
Nilai Tengah & 69,66 \\
Skor Maksimum & 97 \\
Skor Minimum & 54 \\
Rentang Skor & 43 \\
Rata-rata & 73,03 \\
Standar Deviasi & 11,86 \\
Variansi & 140,83 \\
\hline
\end{tabular}

Sumber: Hasil Anaisis Data Primer (2019)

Berdasarkan tabel 6 nilai tertinggi yang diperoleh siswa adalah 97, nilai terendah 54 dengan rentang nilai 43. Jika skor hasil kemampuan menulis paragraf deskriptif siswa kelas $\mathrm{X}_{1}$ SMA Negeri 1 Palopo setelah diterapkan model 
Jurnal Onoma: Pendidikan, Bahasa dan Sastra PBSI FKIP Universitas Cokroaminoto Palopo Volume 6 Nomor 1
ISSN 2443-3667 (print)

ISSN 2715-4564 (online)

pembelajaran kooperatif tipe CIRC dikelompokkan dalam lima kategori menurut Nurkancana (Nurhida, 2015:49), maka diperoleh tabel distribusi frekuensi dan presentase hasil kemampuan menulis paragraf deskriptif seperti ditunjukkan pada tabel berikut ini.

Tabel 7.Distribusi Frekuensi Hasil Kemampuan Menulis Paragraf Deskriptif Siswa Kelas $\mathrm{X}_{1}$ SMA Negeri 1 Palopo Sebelum Diterapkan Model Pembelajaran Kooperatif Tipe CIRC

\begin{tabular}{cccc}
\hline Skor & Kategori & Frekuensi & Presentase \\
\hline $0-54$ & Sangat Rendah & 2 & 7,69 \\
$55-64$ & Rendah & 5 & 19,23 \\
$65-79$ & Sedang & 11 & 42,32 \\
$80-89$ & Tinggi & 4 & 15,38 \\
$90-100$ & Sangat Tinggi & 4 & 15,38 \\
\hline & & 26 & 100 \\
\hline
\end{tabular}

Sumber: Hasil Analisis Data Primer (2019)

Tabel 7 menunjukkan bahwa dari siswa kelas X1 SMA Negeri 1 Palopo yang menjadi sampel pada penelitian (posttest) hasil kemampuan menulis paragraf deskriptif. Siswa yang dikategorikan sangat tinggi 4 siswa (15,38\%),4 siswa $(15,38 \%)$ yang dikategorikan tinggi, 11siswa (42,32\%) yang dikategorikan sedang,5 siswa $(19,23 \%)$ yang berkategori rendah, dan 2 siswa(7,69\%) yang dikategorikan sangat rendah. Hal ini berarti bahwa hasil kemampuan menulis paragraf deskriptif dari 26 siswa pada kelas $\mathrm{X}_{1}$ SMA Negeri 1 Palopo yang diukur dari hasil tes setelah diterapkan model pembelajaran kooperatif tipe CIRCdapat dikategorikan bahwa yang berkategori sedang 42,32\%,jumlah siswa yang berkategori sangat tinggi dengan persentase15,38\%, yang berkategori tinggi yaitu $15,38 \%$, yang berkategori rendah dengan presentase 19,23\%,danuntuk yang berkategori sangat rendah yaitu 7,69\%. Secara umum hasil kemampuan menulis paragraf deskriptif dari 26 siswa pada kelas $\mathrm{X}_{1}$ SMA Negeri 1 Palopo yang diukur dari hasil tes setelah diterapkan model pembelajaran kooperatif tipe CIRC berada pada kategori sedang.

\section{Pembahasan}

Hasil analisis data terlihat bahwa hasil kemampuan menulis paragraf deskriptif siswa kelas $\mathrm{X}_{1}$ SMA Negeri 1 Palopo yang diperoleh melalui tes awal sebelum (posttest) dimulainya pembelajaran dan tes akhir sesudah (prettest) pembelajaran dengan menggunakan model pembelajaran kooperatif tipe CIRC mengalami peningkatan dari kategori sangat rendah diawal pembelajaran dan berada pada kategori sedang sesudah pembelajaran.

Hasil analisis menunjukkan bahwa hasil kemampuan menulis paragraf deskriptif siswa kelas $\mathrm{X}_{1}$ SMA Negeri 1 Palopo secara umum sebelum diterapkan model pembelajaran kooperatif tipe CIRC dikategorikan sangat rendah. Hal ini di tunjukkan dari perolehan nilai rata-rata pretest sebesar 50,07 dari skor ideal 100 
dengan standar deviasi 9,35dan variansi 87,51. Hal ini masih menunjukkan bahwa masih banyak siswa yang belum benar-benar menguasai materi sepenuhnya.

Hasil analisis menunjukkan hasilkemampuan menulis paragraf deskriptif siswa kelas $X_{1}$ SMA Negeri 1 Palopo secara umum setelah diterapkan model pembelajaran kooperatif tipe CIRC dikategorikan sedang, dengan perolehan nilai rata-rata posttest sebesar 73,03 dari skor ideal 100 dengan standar deviasi 11,86 dan variansi 140,83 . Hal ini disebabkan karena meningkatnya kemampuan menulis siswa yang didukung oleh bakat dan kemampuan yang dimilikinya, pendekatan, dan bimbingan belajar yang dilakukan sehingga dapat menguasai materi yang diajarkan atau mencapai ketuntasan belajar.

Dengan demikian secara umum dapat disimpulkan bahwa terjadi peningkatan kemampuan menulis paragraf deskriptifsetelah menerapkan model pembelajaran kooperatif tipe CIRC siswa kelas $\mathrm{X}_{1}$ SMA Negeri 1 Palopo, dengan kriteria hasil kemampuan menulis paragraf deskriptif setelah menerapkan model pembelajaran kooperatif tipe CIRC siswa kelas $\mathrm{X}_{1}$ SMA Negeri 1 Palopo berada pada kategori sedang.

\section{Simpulan}

Berdasarkan hasil analisis data yang telah dilakukan dapat ditarik beberapa kesimpulan yaitu kemampuan menulis paragraf deskriptif siswa kelas X SMA Negeri 1 Palopo sebelum diterapkan model pembelajaran kooperatif tipe CIRC berada pada kategori sangat rendah, kemampuan menulis paragraf deskriptif siswa kelas X SMA Negeri 1 Palopo setelah diterapkan model pembelajaran kooperatif tipe CIRC berada pada kategori sedang, terjadi peningkatan kemampuan menulis paragraf deskriptif siswa kelas X SMA Negeri 1 Palopo setelah diterapkan model pembelajaran kooperatif tipe CIRC. 
Jurnal Onoma: Pendidikan, Bahasa dan Sastra

ISSN 2443-3667 (print)

PBSI FKIP Universitas Cokroaminoto Palopo

ISSN 2715-4564 (online)

Volume 6 Nomor 1

\section{Daftar Pustaka}

Alwi, Hasan, dkk. 2008. Kamus Besar Bahasa Indonesia Edisi Keempat. Jakarta: Balai Pustaka.

Akhadiat, Sabarti. dkk 1996. Pembinaan Kemampuan Menulis Bahasa Indonesia. Jakarta: IKAPI.

Haduyanto. 2001. Membudayakan Kebiasaan Menulis. Sebuah Pengantar. Jakarta: PT. Fikahati Aneska

Keraf, Goris. 1994. Komposisi. Jakarta: Nusa Indah

Kusumah, Encep, dkk. 2003. Menulis 2. Jakarta: Pusat Penerbitan Univeritas Terbuka.

Kusnandar. 2008. Penelitian Tindakan Kelas. Jakarta: Rajawali Pers.

Liang Gie, The. 2002. Terampil Mengarang. Yogyakarta: Andi.

Melki. 2011. Peningkatan Kemampuan Menulis Ringkasan dengan Metode Pembelajaran Kooperatif Tipe CIRC pada Siswa Kelas XI IPA 1 SMA Negeri 1 Baebunta Kabupaten Luwu Utara: Skripsi. Makassar: UNM.

Solihatin, Etin. 2007. Cooperative Learning. Jakarta: Bumi Aksara

Sugiyono. 2012. Metode Penelitian Kuantitatif kualitatif dan R\&D. Bandung: Alfabeta

Tarigan, Hendry Guntur. 2008. Menulis sebagai Keterampilan Berbahasa. Bandung: Angkasa.

Wardhani, IGAK. 2008. Penelitian Tindakan Kelas. Jakarta: Universitas Terbuka. Yunus, Mohammad \& Suparno. 2007. Keterampilan Menulis. Jakarta: Universitas Terbuka 